\title{
ITALIAN META-REFLECTIONS ON SELF-TRANSLATION: AN OVERVIEW OF THE DEBATE
}

\section{Tiziana Nannavecchia}

\section{Discourses around self-translation: signs for a fruitful decade ahead}

In 2010, two events entirely dedicated to self-translation took place in Italy: a seminar held in Udine in March (L'autotraduzione nelle letterature migranti) and a large-scale international conference on the subject, the first of its kind, in Pescara (Autotraduzione: teoria ed esempi fra Italia e Spagna (e oltre)) in November. It is surprising that, for a practice that has always existed, scholars only decided to join efforts internationally and exchange on the topic less than a lustrum ago. However, since then, four more international conferences have been held; an annual effort that demonstrates the willingness to maintain a dialogue on a topic that is far from being exhausted or fully understood.

Certainly, the recent increasing interest in self-translation — the 2000s exhibit an ever-growing number of interventions internationally with articles, monographs, panels and conferences being dedicated to the subject - attests its importance and its relevance for international scholarship across many scientific disciplines ${ }^{1}$.

At the centre of this meta-reflection on self-translation is Italy, where the first speculations on the phenomenon started back in 1998/9: these years coincide with the seminar on Autotraduzione e interculturalità nella poesia europea, jointly organized by the City of Florence and the poetry journal Semicerchio, whose proceedings were subsequently published in the aforementioned journal under the title La lingua assente (1999) - a title that suggests both the (then) absence of discussion on self-translation and the idea of the self-translator's visibility/invisibility.

Among the many global contributions to the question produced since then in the realm of Translation Studies ${ }^{2}$, special attention should be given to conferences:

\footnotetext{
1 The phenomenon of self-translation is fascinating inasmuch as it offers basis for considerations beyond its linguistic implications; history, philology, literature and psychology are some of the viewpoints that could be adopted in approaching the questions. Similarly to the way the real flourishing of Translation Studies has coincided with its growing multidisciplinarity, self-translation as an independent field of research could benefit from the insights brought by different disciplines.

2 The online bibliography on self-translation, collected and constantly updated by Eva Gentes (http://self-translation.blogspot.ca), is a good point of reference to understand the wealth of works on the topic. I will limit the enquiry to just some among the most notable works and events dedicated to self-translation. Various scholarly journals collected articles on self-translation, such as in the above-
} 
places and means to exchange knowledge among international researchers, and hubs where new ideas are conceived, attesting to the liveliness of a field and providing a good overview on its current state.

After the Pescara conference, four other international gatherings on the topic took place: Autotraduzione. Testi e contesti (in Bologna, in May 2011), Autotraduction: frontières de la langue et de la culture (in Perpignan, France, in October 2011), L'autotraduction littéraire: perspectives théoriques (in Udine, in October 2012), and Self-Translation in the Iberian Peninsula (in Cork, Ireland, in September 2013). The second decade of the 2000s has thus seen a systematic interest and a programmatic willingness to start the dialogue on self-translation, a keenness that has originated within Europe's borders, more specifically in Italy. For this reason, and for the international relevance and spectrum offered by the papers given on these occasions, I will give an overview on the visibility/invisibility of self-translation in Italy based on the three volumes published by the same centres of research that organized the three above-mentioned Italian seminar and conferences.

Despite the evidence that most of the voices around self-translation have been originating from within the heart of Europe, more specifically Italy and Spain $^{3}$, none of the studies on the topic conducted so far has actually investigated the reasons for this localized attention, an issue that probably deserves further investigation. If it is true that self-translation "has of late received considerable attention in the more culturally inclined provinces of translation studies" (Grutman 2009, p. 257), one may consequently infer that this cultural inclination to study self-translation is but a result of the heterolingual disposition that historically distinguishes these areas.

As stated above, Italy seems to have come to represent an important hub for the study and discourses on self-translation. The three volumes at the core of this analysis - L'Autotraduzione nelle letterature migranti (2011), Autotraduzione: Teorie ed esempi fra Italia e Spagna (e oltre) (2012) and Autotraduzione e riscrittura (2013) - are the fruit of coeval research conducted at three Italian universities: Udine, Pescara and Bologna.

mentioned Semicerchio 20-21 (1999); Quimera 210 (2002); In Other Words 25 (2005); Atelier de traduction 7 (2007); Quaderns 16 (2009); Oltreoceano 5 (2011); Orbis Litterarum 30(3), 2013.

3 It is worth mentioning that the Universitat Autònoma de Barcelona (Facultat de Traducció i Interpretació) boasts a research group, founded by Francesc Parcerisas and Helena Tanqueiro, which have devoted their attention to the question since 2002. http://grupsderecerca.uab.cat/autotrad 
The volumes include articles by scholars operating in the field from an international perspective: from Europe to Australia, via North America. However, while the first two in terms of publishing date, L'Autotraduzione nelle letterature migranti (2011) and Autotraduzione: Teorie ed esempi fra Italia e Spagna (e oltre) (2012) have chosen to give voice to the multiplicity of tongues in which the dialogue around self-translation has been taking place - Italian, English and Spanish - the latest among the three, Autotraduzione e Riscrittura (2013) presents papers solely in Italian, the interventions delivered in either English or Spanish at the original conference (which took place at the University of Bologna Alma Mater Studiorum, in May 2011) having in fact been translated afterwards expressly for the publication of the volume. This choice of translating all the interventions into Italian seems to clash with the will to internationalize the debate, restricting the accessibility/readability (visibility) of these proceedings to an Italian speaking audience.

For this reason, with the willingness to extend the important contributions offered in these three volumes to a wider audience - who may not be proficient in Italian - I will proceed to present an overview on the Italian debate on selftranslation. Starting by highlighting who participated in said debate, I will then focus on the core of the question: the manner in which these researchers contributed to the advancement of self-translation as an independent field of research in Italian scholarship.

\section{The self-translation scholar's invisibility}

It has already been specified that the aim of this article is to present the reader with an overview on the debate around self-translation that has been taking place in Italy over the past lustrum: specifically since the date of the first conferences, in 2010 in Udine and in Pescara, to ever take place on the subject. It would nonetheless be unfair to proceed with such an analysis neglecting the role of the scholars who are contributing to the flourishing of the question: often obscured by the name of the writers they analyze, these academics are the principal makers of the field as we know it today. 
The three volumes taken into consideration count a number of 55 international scholars ${ }^{4}$ debating the topic of self-translation in Italian, Spanish and English. Without resorting to the question of nationality, which in the transnational world we live in today and in Translation Studies especially is anything but relevant, and from which the choice of the writing language does not always depend, I will instead highlight the country where those scholars work. The environment in which scholars develop their theories highly influences the directions their study will take, as demonstrated by the similarities of research conducted by academics working at the same university.

A full fifth of the authors who have been participating to the discourse around self-translation in Italy do not work in this country. Outside of the Italian peninsula, Spain is the country that contributed most interventions by: Julio César Santoyo, Juan Miguel Valero Moreno, Avelina Carrera de la Red (all of which participated in the Pescara conference, dedicated in part to self-translation in Spain Autotraduzione: Teoria ed esempi tra Italia e Spagna) and Xosé Manuel Dasilva. Anthony Cordingley and Chiara Montini represent research conducted in France; the United Kingdom appears with contributions by Susan Bassnett and Martin Mclaughlin. The rest of Europe only appears with one article by two Italian researchers based respectively in Germany, Valentina Piazza, and Hungary, Biagio D’Angelo (who has relocated since to Brazil). Extra-European viewpoints are scarce, with only Canada and Australia being represented. It is worth indicating the presence of two scholars from Canada: Rainier Grutman - whose theoretical tenets form the foundations of many of the articles presented - and Trish Van Bolderen; Australia, however, only appears once in the three volumes with the one article by Rita Wilson.

As per the Italian focus on the question, the three University centres that are most active in this area are the ones that hosted the conferences: the Universities of Pescara, Bologna and Udine. It is remarkable that the interest in self-translation in Italy is generated within departments of modern languages and literatures, rather than translation schools as such; despite having courses in the translation discipline, two of these three Universities (namely Pescara and Udine) actually do not have an

\footnotetext{
${ }^{4}$ I am excluding here the sections dedicated to the book reviews and bibliographical notes. Four authors - specifically Rainier Grutman, who provides a theoretical opening for two of the volumes, and Italians Alessandra Ferraro, Paola Puccini, Valeria Sperti appear with their contributions in two of the three volumes.
} 
independent translation department, while the University of Bologna does (at its Forlì campus $)^{5}$.

Scholars Paola Desideri, Alfonso de Petris, Francesca Leonetti, Marcial Rubio Arquez, Maria Rita Leto, Federica D’Ascenzo and Andrea Mariani are all affiliated to the Department of Modern Languages, Literatures and Cultures of the Università Gabriele D'Annunzio of Pescara, host of the 2010 conference.

At the University of Udine, it is the Department of Modern Languages, Literatures and Cultures that conducts research on self-translation from the various approaches (Francophone literatures, Hispanic literatures, linguistics, etc.) held by academics Alessandra Ferraro, Fabiana Fusco, Deborah Saidero, Sagrario del Río Zamudio and Andrea Schincariol.

The largest group of researchers on the topic, however, works at the University of Bologna, not at the School of Translation based in Forlì, but rather at the Department of Modern Languages, Literatures and Cultures. The participants from Bologna are: Umberto Eco (who, together with Susan Bassnett had the role of opening the Bologna conference), Barbara Ivančić, Roberto Mulinacci, Paolo Leonardi, Andrea Ceccherelli, Monica Perotto, Monica Marsigli, Giuseppina Brunetti, Gabriella Imposti, Irina Marchesini, Alessandro Niero, Silvia Albertazzi, Paola Puccini, Claudia Tatasciore, Alessandro Zironi, Enrico Monti, Gino Scatasta, Fabio Regattin, and Tina Montone.

Individual scholars from other Italian universities represent the increasing interest in the question scattered around the peninsula: Anna Lapetina and Valeria Sperti (University of Basilicata), Irina Bajini (University of Milan), Sergio Lubello (University of Salerno), Antonio Gargano (University of Naples), Cristina Montagnani (University of Ferrara), Francesco P. Di Teodoro (Polytechnic University of Turin), Laura Salmon (University of Genova), and Francesco Santi (University of Cassino).

\section{A geo-linguistic and historical mapping of self-translators}

Let us move from the geographical mapping of scholars working on selftranslation to the self-translators studied and their geo-linguistic and historical location.

\footnotetext{
${ }^{5} \mathrm{http}: / /$ www.dit.unibo.it
} 
The first volume to appear, the Udine proceedings (2011), presents the reader with three main geographical sections: Canada, Latin America and Italy. What these three areas have in common is the experience of migration in the 20th century. The methodological and thematic framework chosen to tackle the question of selftranslation is that of mobility. The volume appeared, in fact, as an issue of Oltreoceano, a journal that publishes the results of research on migrant literatures conducted within the Centro Internazionale Letterature Migranti of the University of Udine. As asserted in the opening editorial by the centre's founder, Silvana Serafin, examining self-translation is necessary to gain understanding of the "ampio spettro della letteratura migrante di cui si stanno delineando con forza sempre maggiore tutti gli elementi tematici e morfologici, necessari alla costruzione di un quadro sistematico complessivo del genere"6 (Serafin in Ferraro 2011, p. 7). Self-translation thus becomes the key to unlock the intricate chain of meanings underlying migrant literature. In most cases, the geographical area under which the authors are grouped represents their 'country of arrival', with the exception of Nancy Huston, for whom Canada represents the point of departure.

Canada gets the lion's share ${ }^{7}$, being at the centre of six out of the eleven essays, bearing witness to the relevance of the self-translation practice for multicultural Canada and its hyphenated authors. Five Italian-Canadians and one Franco-Canadian (as opposed to French-Canadian) epitomize the phenomenon of selftranslation in migrant literature: Mario Duliani (who self-translates from French to Italian), Dôre Michelut and Gianna Patriarca (alternating between Italian, regional dialects and English, so that it is difficult to identify the directionality of the translation flows), Marco Micone (from French to Italian, and back into French), Antonio D'Alfonso and Nancy Huston (who both self-translate bi-directionally between English and French).

In an imaginary migratory Southbound journey, the volume moves onto the South American continent: here we are introduced to translingual literature and the exilic self-translations of Argentinian Manuel Puig, Chilean-Canadian Camila Reimers and her English to Spanish self-translation of children's literature, Bolivian-

\footnotetext{
${ }^{6}$ Broad range of migrant literatures, for which all the morphological and thematic elements needed to build a comprehensive and systematic framework for the genre are emerging with increasing force. [My translation]

7 The preference for the North American country is to be attributed to the presence of the Centro di Cultura Canadese at the University of Udine, of which several scholars participating in the volume are founders and members.
} 
Canadian Alejandro Saravia (who self-translates among Spanish, English and French in all directions), the English/Spanish heterolingual writings of Mexican-American Sandra Cisneros, the bidirectional English-Spanish translations of Porto Rican Rosario Ferré, and Chinese-Peruvian-Hawaiian Siu Kam Wen and his Spanish to English self-translations.

The latter part of the volume is dedicated to hyphenated Italians, the "emigranti intellettuali" (Bajini in Ferraro, p.103) who willingly decided to abandon their motherland/tongue: the trilingual Italian-Mexican author Carlo Coccioli (whose production, studied in two essays, oscillates between Italian, Spanish and French), Fabio Morabito and his reluctance to self-translate his Spanish poetry in his native tongue, Francesca Gargallo and her 'liberation' in writing in hybrid Spanish, Marco Perilli and self-translation as a method to get closer to writing creatively in the foreign language, and the 'confessions' by self-translator Biagio D'Angelo, for whom selftranslation is an act of "decentramento" (D'Angelo in Ferraro, p.117) reflecting the realization of the multiplication of the identities of the migrant author and his detachment from his native land/tongue and his redoubling into the new adopted tongue, Spanish.

The Udine volume opened with the idea of Italy as a land of departure for the migrant author (as in the case of the Italian-Canadians presented in the first section) and closes with the idea of Italy as port of arrival, with the cases of self-translation of four hyphenated Italian women: the parallel Italian-Tigrinya self-translations of Eritrean-born Ribka Sibhatu, the naturalized Italian from Cameroon Geneviève Makaping who "chooses to foreground processes of self-translation as acts of symbolic self-assertion and empowerment" (Wilson in Ferraro, p. 129), heteroglossia and self-translations from orality in the work of Somali Ubax Cristina Ali Farah, and métissage and the overlapping of languages (Ethiopian Oromo, Italian and Turin dialect) in Maria Abbebù Viarengo's writing.

All the scholars who participated in this first volume focussed their attention on $20^{\text {th }}$-century writers operating mostly in Italian, English, French or Spanish. Despite the presence of the aforementioned African-Italian writers, which could have broadened the discourse with a different perspective outside the canonical European 
languages, their (potentially enlightening) contribution to the question of selftranslation remains largely unexplored ${ }^{8}$.

A different approach, both geo-linguistically and historically, was adopted by the researchers who contributed to the volume: Autotraduzione: Teorie ed esempi tra Italia e Spagna (2012). By expanding beyond the 20th century, the volume succeeds in demonstrating that self-translation is anything but recent. Starting from Julio-César Santoyo's overview of the practice in the Middle Ages, which comprises 27 selftranslators and 38 self-translations, the period of Humanism is investigated through the works of Italians Leon Battista Alberti - one of the few humanists in the 1400s to self-translate his works from the vernacular to Latin (and vice versa) - and Giannozzo Manetti and his theories of translation, Spaniards Antonio de Nebrija and Alonso de Palencia, who highlight "las dificultades del bien romançar la lengua latina" (Gargano in Árquez and D'Antuono 2012, p.132), Borso d'Este and selftranslations within the Este court in Ferrara, Enrique de Villena and El Tostado, Sor Juana Inés de la Cruz and Fray Luis de Leòn and their self-translations between sacred and pagan, Daniele Barbaro and Alfonso de Ulloa.

While the title seemingly circumscribes the research to two European countries, some of the papers presented move across these borders, extending the analysis to territories outside Spain and Italy. We thus find an outline of the history of self-translation in Croatian literature, a study of contemporary French writer Jacqueline Risset and her self-translations from and into Italian, and an interesting excursion into the intersemiotic translations of American artists Georgia O'Keeffe and Elizabeth Bishop.

The range of authors, geographically, linguistically and historically speaking, is even wider in the Bologna conference proceedings (2013): although the main focus is self-translation in the 1900 s, some of the analyses proposed corroborate the claim that the practice was already frequent in the Middle Ages, while also involving languages outside of the European framework.

Even in Italy, at the mere mention of the word self-translation, one cannot but think about Samuel Beckett. His figure, which seems to inspire a sense of awe, is present - even when not expressly mentioned - behind almost every article of this collection. His presence is recurrent in the analyses mainly because, as affirmed by

\footnotetext{
${ }^{8}$ The question of orality in self-translation, for example, only receives little attention, while it would be interesting to examine the issue more in depth.
} 
Grutman in the volume, his symmetric work in English and French is often held to embody the "quintessenza dell'autotraduzione" (Grutman in Ceccherelli et al. 2013, p. 47). At least 3 of the 31 essays are dedicated to the "autore equilingue" (Montini in Ceccherelli et al. 2013, p. 141), and his name comes up in most of them.

Nabokov also makes a significant appearance with two essays entirely devoted to the parallelisms and divergences between his work as a translator between Russian and English (in both directions) and as a self-translator (from Russian into English), as well as to the close collaboration with his son, Dmitri. The exilic nature of Nabokov's self-translated work links him to another Russian writer: Iosif Brodskij, the topic of Alessandro Niero's essay in the volume.

Exile is at the centre of two other self-translators introduced here: Argentinianborn Chilean Ariel Dorfman (English and Spanish) and Austrian-American Ruth Klüger (German into English), who mark the use of self-translation in the genre of autobiography as a means of highlighting the doubling of identity in exilic conditions, an idea also present in Susan Bassnett's paper, who reminds us of Rabrindanath Tagore and his Bengalese to English self-translations, which stress the general idea of the self-translator as a rewriter, a "rifacitore", a remaker, in Roberto Mulinacci's words (in Ceccherelli et al. 2013, p. 107).

20th-century migrant writers occupy an important part in the debate: ItalianCanadian Antonio D'Alfonso and Marco Micone, Franco Biondi and the ItalianGerman "bidirezionalità duplice" of his self-translations (Tatasciore in Ceccherelli et al. 2013, p. 365), Danish Karen Blixen and her self-translations from English into the mother tongue, French-American Raymond Federman (bidirectional English-French), Carlo Coccioli, and Nancy Huston's “ambiguità linguistica” (Sperti in Ceccherelli et al. 2013, p. 381).

At the turn of the century, the Wiener Moderne offer us two fine examples of self-translation in the Austro-Hungarian empire: Rainer Maria Rilke and his many bidirectional French-German self-translations, and poet Hugo von Hofmannsthal, for whom self-translating his German into French was a creative rebirth.

An entire essay (Ceccherelli) is dedicated to Polish self-translators of the 1900s in order to draw attention to an often-neglected area: Stanisław Przybyszewski (German), Tadeus Rittner (German) and Wacław Sieroszewski (Russian) signal the regularity of self-translation in a country where the language of the Other was imposed by the invaders before World War I; Bruno Jasieński (Russian), Stanisław 
Ignacy Witkiewicz (French), Debora Vogel (Yiddish), and Stanisław Kubicki (German) represent the experimental period between the two wars; Stefan Themerson (English), Maria Kuncewiczowa (English), Stanisław Barańczak (English), Witold Gombrowicz (Spanish) and Czesław Miłosz (English) exemplify self-translation as a response to exile after the two wars.

With Monica Perotto, we move further East to analyze the phenomenon of the perevod avtora (author's translation) in the former USSR. The presence of the Russian language — seen as the official, High variety — next to the local Low varieties made literary bilingualism and literary diglossia more than a rare phenomenon: Čingiz Gusejnov, Turusbek Madylbaj, Ajtmatov, Anar, and Viktor Koz'ko, are just some of the representatives of this diglossia.

A section of the book is dedicated to the exploration of self-translation in the period preceding the $20^{\text {th }}$ century: from the Latin-Catalan self-translations of Ramon Llull in the XIII-XIV centuries and his contemporary Florentine Francesco da Barberino and his self-translations from vernacular to Latin, to the French Jean Gerson (and his Latin and French productions) and Charles d'Orléans (from English, the language of exile, to his native French). Special attention is paid by Dasilva to self-translation in the Iberian Peninsula between the XV and the XVIII centuries. During the period of Luso-Castilian bilingualism many Portuguese authors selftranslated their texts into Spanish: Condestável D. Pedro de Portugal, Frei António de Portalegre and Pedro Nunes, among others. The last case offered is that of XVIcentury Flemish poet Jan van der Noot, the only representative - in the whole of the three volumes - of the linguistic richness of the Low Countries: a polyglot, he wrote extensively in French, Latin and Dutch, self-translating his works among these languages in order to obtain literary glory.

Autotraduzione e Riscrittura closes with three authors who have approached self-translation for stylistic reasons, as a literary device: T.S. Eliot, who reuses previously written French material, translates and inserts it into The Waste Land, and the bizarre case of Boris Vian's J'irai cracher sur vos tombes and his English selftranslation (a pseudo-translation under the pseudonym of the fictitious American author Vernon Sullivan).

\section{Between theory and practice}


There seems to be a tendency among scholars to side with two imaginary fronts: the theoretical and the empirical. Because of its relative novelty, the field is still in search of solid theoretical foundations, whose construction seems to be in the hands of those scholars who specifically carry out research in the field of Translation Studies and linguistics.

Such is the case of Rainier Grutman, who took part in two of these conferences; even in these occasions his is the most commonly adopted (and cited) definition of self-translation: "the act of translating one's own writings into another language and the result of such an undertaking" (Grutman 2009, p. 257). As highlighted by Grutman, and as proven by the examples provided in the three volumes, the term self-translation - this also applies to the Italian autotraduzione, the Spanish autotraducción, and the French autotraduction (just to compare the languages I am familiar with) - indicates a duplicity of uses: the term may, in fact, indicate both the process of translating (the act) and the work translated (the result).

Despite being universally accepted and attested, some scholars still doubt the existence of self-translation in its 'pure state': such is the case of Umberto Eco who was in charge of giving the keynote plenary that opened the Bologna conference in 2011 - who affirms that "è dubbio se esista l'autotraduzione allo stato puro" (Eco in Ceccherelli et al. 2013, p. 26). Rather, Eco states, translating one's own work in another language is more a matter of rewriting a different book - the concept of rewriting was central to the above mentioned conference - a rewriting practice that can be read in terms of self-plagiarism.

The concept of plagiarism applied to self-translation is not new; pleading guilty, Borges accused himself of plagiarizing his own work in the different languages he used: "I admit it: I repeat myself. I confirm it: I plagiarize" (Jorge Luis Borges, quoted in Kristal 2002, p. 135). According to Scatasta, another famous self-translator, T.S. Eliot, is culpable of self-plagiarism. He translated into English some verses of his own French poem Dans le restaurant (1918) and inserted and recontextualized them in The Waste Land (1922). Upon closer comparison of Eliot's bilingual corpus, the practice appears habitual, and allows Scatasca to number Eliot among those writers who "ruba a se stesso" (Scatasca in Ceccherelli et al 2013: p. 423, 428). For Eliot, however, self-translation (or self-plagiarism) is seen as a cure to the illness of writer's block, "la guarigione da un blocco creativo" (p. 430). 
The motives behind self-translation (or self-plagiarism or rewriting) remain a topic of interest. Susan Bassnett (in Ceccherelli et al. 2013) unfolds some of the reasons for which authors decide to self-translate: the desire to find their real poetical voice, a search for a poetical identity, the necessity to widen their audience and the political role of promoting a minority language. In the same volume, Grutman reminds us in which environments self-translation is more likely to occur: the presence of language minorities, contexts of migrancy and exile, and postcolonialism.

I will conclude with a brief remark on the more empirical work dedicated to the authors mentioned in the previous section and carried out especially by those scholars who specialize in modern literatures. These analyses explore the author's relationship with her native and adopted languages, the time and manner in which self-translations follow the first work, and the directionality of the translation flow. These empirical works on authors tend to regroup around two issues: the question of linguistic identity in the context of migrancy (one of the volumes is entirely dedicated to the topic) and exile, and the precise stylistic use of languages as a vehicle of an author's poetics.

\section{Self-translation as a (yet) developing field}

It is time to draw some conclusions regarding the discourse around selftranslation in Italy. Moving beyond the search for definitions that initially characterize a field, the recent Italian investigations contained in these three collections seem to concentrate around an empirical study of self-translation with three precise aims: describing self-translation as/in migration (Udine); describing selftranslation as a practice that has always existed (Pescara) and translation as a form of rewriting (Bologna). These volumes have attempted to solve some of the issues that had been previously underlined in the study of the field: a rather exclusive focus on contemporary self-translators, Eurocentric discourse and a depiction of the practice as being purely linguistic in nature.

As mentioned above, in self-translation, as in Translation Studies as a whole, we perceive the need to move away from these purely linguistic concerns. Nonetheless, many works still deal with the linguistic aspects of self-translation - as in a necessity to connect a process yet not fully understood to better-known categories. As a consequence, despite claiming a distancing from the early Translation Studies concerns around the concept of equivalence, many scholars seem preoccupied 
with researching underlying networks of sameness, or correspondence, between the two (or more) texts produced by the author/self-translator.

By presenting us with authors who self-translated their works in the Middle Ages and others who represent extra-European perspectives (mainly from the Americas), we are encouraged to stop thinking in closed categories and, even more specifically, to abandon the dichotomy between original and copy in order to embrace a fluid and alternative idea of translation: "Il concetto di originale è molto più fluido che in altri tipi di traduzione, $e$ in effetti sorgono dubbi addirittura sull'esistenza stessa di un originale" (Bassnett in Ceccherelli et al. 2013, p. 37).

Some issues that have become popular with the Cultural Turn in Translation Studies, have received little attention: questions of gender, the post-colonial world or the idea of cultural translation or the social role/position of self-translators / translations in the respective countries in which they appear, just to name a few.

The question of self-translation remains firmly centred in the Western world, with English being the most investigated language. Moreover, despite Italy having offered at various times examples of self-translators - Carlo Goldoni ${ }^{9}$ (1707-1793), Luigi Pirandello (1867-1936), Giuseppe Ungaretti ${ }^{10}$ (1888-1970), Andrea Zanzotto (1921-2011), Beppe Fenoglio ${ }^{11}$ (1922-1963), Pier Paolo Pasolini (1922-1975), and Fausto Cercignani (1941), among others - the discourse on self-translation in Italy is far from having explored the practice in the peninsula. In fact, among all the interventions made in the course of the Italian conferences on the topic, only one paper (Sergio Lubello's) tackled of the big names in Italian self-translation: Pirandello.

Moreover, in her analysis of five monographs entirely dedicated to selftranslation at the time her article had been written, Trish Van Bolderen (in Ceccherelli et al. 2013) underlined that the question had often been connected to literary discourse; very little had been said or done about self-translation of scientific and

\footnotetext{
${ }^{9}$ Only mentioned in the article by Paola Desideri in the Pescara conference proceedings (2012), Goldoni self-translated from the Venetian dialect into Italian and from French to Italian. For the latter see the article Goldoni Traducteur de Lui-Même by Laurence Boudart.

${ }^{10}$ See for example Giuseppe E. Sansone Ungaretti Autotraduttore in Lavoro Critico, 28 (1989), pp. 1321.

${ }^{11}$ Chiara Montini, who participated to the Bologna Conference in 2011, did study the role of Beppe Fenoglio as self-translator and presented a work on the topic entitled Exil et retour: Beppe Fenoglio et l'entre-deux de l'autotraduction at the 2011 conference in Perpignan, France.
} 
technical texts ${ }^{12}$. A few years have passed since the date of her survey (conducted in 2010) - all three volumes reviewed here were published after that date — yet we can safely affirm that the results of that first analysis are still valid, as far as the Italian debate on self-translation is concerned.

Not only is the first - in terms of publishing date, the Udine volume — of the three volumes dedicated to literature, but it specifically focuses on the genre of migrant literature, with an eye on authors of Italian origin or the 'new Italians'. The Pescara conference proceedings, comprising many articles dealing with literary and religious texts (which are still considered as belonging to the humanities), broadens the discourse by offering two cases of intersemiotic translation: the curious interconnecting paths of American painter Georgia O'Keeffe and poet Elizabeth Bishop who self-translate their works into each other's domain, poetry and painting.

In Autotraduzione e Riscrittura, Umberto Eco offers a thought-provoking insight into the question: moving away from purely literary discourse, he shares his own experience in self-translating - he would probably disagree with my choice of the term - his English Theory of Semiotics (1976) into the Italian Trattato di semiotica generale (1975), in which he refers to the former as to a "prima stesura" (6), a first draft $^{13}$. After reiterating his scepticism towards the idea of translating one's own writing - “[n]on crederete mica che lo abbia ritradotto!" (Eco in Ceccherelli et al. 2013, p. 26-27) - Eco states that even the translation of non-literary texts such as this is nothing but rewriting (which would become the leitmotiv of the volume).

Thus, except for three presentations on intersemiotic translation and Eco's testimony, the Italian debate around self-translation is still very firmly anchored in the artistic literary field. Equally significant is the fact that research on the topic work is mainly carried out in departments of modern languages and literatures. As evidenced by a wealth of contributions from the Italian peninsula, interest in the topic is on the rise; in anticipation of the next fruitful decade, one may hope for a real internationalization and a full interdisciplinarity of the debate.

\footnotetext{
12 A workshop entitled Self-Translation as Transfer of Knowledge at the Center for Literary and Cultural Research in Berlin, November 27-28, 2014 will be dedicated to the issue and may offer new, stimulating insights.

${ }^{13}$ Although in the foreword to the English text he then affirms: "I have now retranslated it into Italian as a brand new work (Trattato di semiotica generale)" (Eco 1976: viii). Despite the dates of publishing of the English and Italian volumes appear to prove the opposite, the English 'draft' seems to be the base for his Italian version.
} 


\section{References}

ÁRQUEZ, Marcial Rubio \& D'ANTUONO, Nicola (eds.). Autotraduzione: teoria ed esempi fra Italia e Spagna (e oltre). Milano: LED, 2012.

CECCHERELLI, Andrea et al. (eds.). Autotraduzione e riscrittura. Bologna: Bononia University Press, 2013.

ECO, Umberto. Trattato di semiotica generale. Milano: Bompiani, 1975. A theory of semiotics. Bloomington: Indiana University Press, 1976.

FERRARO, Alessandra (ed.). L'Autotraduzione nelle letterature migranti. Udine: Forum, 2011.

GRUTMAN, Rainier. Self-translation. In: BAKER, Mona; \& SALDANHA, Gabriela (eds.) Routledge Encyclopedia of Translation Studies. $2^{\text {nd }}$ ed. New York: Routledge, 2009. p. 257-260.

KRISTAL, Efraín. Invisible Work: Borges and Translation. Nashville: Vanderbilt University Press, 2002. 